\title{
Masculine and Feminine Traits Perception of MBA Students
}

\author{
Jaya Bharti $^{1 *}$, Sneh Lata Rao ${ }^{2}$
}

\section{ABSTRACT}

This is an exploratory Ex-post facto research orientation with the aim was to study the gender differences in perception of masculine and feminine qualities for Male and Female MBA Students. It also hypothesized to know the significant difference among Males and Females in perception of Masculine qualities, Males and Females in perception of Feminine qualities, masculine traits for MBA and Female Students, Male and Female successful Managers, feminine traits for MBA Male and Female students and successful Male and Female Managers, significant interaction effects of gender and target person (male and female MBA student's Male and Female successful managers) on perception of masculine traits and significant interaction effects of gender and target person on perception of feminine traits. In this study, 40 subjects (male and female MBA students) .Subjects were assessed using Adjective checklist (Zaidi and Agrawal, 2003 doctoral work in progress) contains 80 qualities.43 males and 43 females by Harrison Gough Adjective Checklist The results of the study reveals that the perception of the male MBA students was found to be non-significant for both individual and interactive levels. This suggests that the male student perceive that no change at the organizational level is wanted in order of better functioning. They perceive the same traits for the successful managers for themselves as for they for female managers.

Keywords: Masculine, feminine Traits, MBA Students.

Organizational theory has traditionally described organizations as gender neutral but for the past decade feminist scholars have questioned the validity of those depictions. They argue that "gendered organizations" reinforce traditional notions of male dominated hierarchies, placing women primarily in role of low status and low prestige. Gender is an important issue in, the set of corporate India. Where there are some significant differences there are some similarities in the perception of male and female managers in several key areas.

\footnotetext{
1 JRF, Department of Psychology, Lucknow University

${ }^{2}$ Research Scholar, Department of Psychology, Lucknow University

*Responding Author

(C) 2016 I J Bharti, S Rao; licensee IJIP. This is an Open Access Research distributed under the terms of the Creative Commons Attribution License (http://creativecommons.org/licenses/by/2.0), which permits unrestricted use, distribution, and reproduction in any Medium, provided the original work is properly cited.
} 


\section{Masculine and Feminine Traits Perception of MBA Students}

Gender refers to everything else associated with an individual's sex, including the role, behaviours, preference and other attributes that define what it means to be a male or a female in a given culture. The attributes, behaviour, personality characteristics and expectancies associated with a person's biological sex in a given culture.

Gender stereotypes can have negative connotations, like those above, but they can also have positive connotations, even though they're often over-generalized. For instance, the notion that women are better caregivers than men is a positive connotation, but it is a generalization and not necessarily true in all cases. This is similarly so for the notion that men are better providers than women, which while positive, can be disproved by looking at cases where men have abandoned their families and defaulted on child support.

Gender stereotypes serve a necessary function in society by reaffirming traditional roles about men and women.

Gender stereotyping refers to the practice of ascribing to an individual woman or man specific attributes, characteristics, or roles by reason only of her or his membership in the social group of women or men. Gender stereotyping is wrongful when it results in a violation or violations of human rights and fundamental freedoms. An example of this is the failure to criminalize marital rape based on societal perception of women as the sexual property of men.

\section{Female Gender Stereotypes:}

- Women are supposed to have "clean jobs" such as secretaries, teachers, and librarians

- Women are nurses, not doctors

- Women are not as strong as men

- Women are supposed to make less money than men

- The best women are stay at home moms

- Women don't need to go to college

- Women don't play sports

- Women are not politicians

- Women are quieter than men and not meant to speak out

- Women are supposed to be submissive and do as they are told

- Women are supposed to cook and do housework

- Women are responsible for raising children

- Women do not have technical skills and are not good at "hands on" projects such as car repairs

- Women are meant to be the damsel in distress; never the hero

- Women are supposed to look pretty and be looked at

- Women love to sing and dance

- Women do not play video games

- Women are flirts

- Women are never in charge 


\section{Masculine and Feminine Traits Perception of MBA Students}

\section{Male Gender Stereotypes:}

- All men enjoy working on cars

- Men are not nurses, they are doctors

- Men do "dirty jobs" such as construction and mechanics; they are not secretaries, teachers, or cosmetologists

- Men do not do housework and they are not responsible for taking care of children

- Men play video games

- Men play sports

- Men enjoy outdoor activities such as camping, fishing, and hiking

- Men are in charge; they are always at the top

- As husbands, men tell their wives what to do

- Men are lazy and/or messy

- Men are good at math

- It is always men who work in science, engineering, and other technical fields

- Men do not cook, sew, or do crafts

\section{METHODOLOGY}

\section{Statement Of The Problem:-}

The main purpose was the study to ascertain the gender differences in perception of masculine and feminine qualities for Male and Female MBA Students.

\section{Types of research:}

It is an exploratory Ex-post facto research orientation. Ex-post facto originally is systematic empirical inquiry in which the scientist does not have direct control of independent variables because their manifestation have already occurred or because they are intestinally not made without direct intervention from concomitant variation of independent and dependent variables. It is $2 \times 4$ mixed factorial design.

\section{Hypothesis:}

- There would be significant difference among Males and Females in perception of Masculine qualities.

- There would be significant differences among Males and Females in perception of Feminine qualities.

- There would be significant difference of masculine traits for MBA and Female Students, Male and Female successful Managers.

- There would be significant differences of the feminine traits for MBA Male and Female students and successful Male and Female Managers.

- There would be significant interaction effects of gender and target person (male and female MBA student's Male and Female successful managers) on perception of masculine traits.

- There would be significant interaction effects of gender and target person on perception of feminine traits 


\section{Masculine and Feminine Traits Perception of MBA Students}

\section{Variable:}

INDEPENDENT VARIABLE-

$>$ Gender (male and female),

$>$ MBA students

$>$ Successful managers

DEPENDENT VARIABLE-

$>$ Masculine qualities (possessed by male students and successful male mangers)

$>$ Feminine qualities (possessed by female students and successful female managers)

\section{Sample:}

The sample consists of 40 subjects (male and female MBA students) among those 40 where the Indian Institute of Management (5 boys and 5 girls) and Lucknow University (5 boys and 5 girls). Mean age of all girls and boys is 28 years they were in third semester. Managers (5 male and 5 female) were taken from HDFC Bank in Hajratganj and LIC in Aliganj. The mean age of all managers is 37 .

\section{Tools:}

Adjective checklist (Zaidi and Agrawal, 2003 doctoral work in progress) contains 80 qualities.43 males and 43 females by Harrison Gough Adjective Checklist. Also two questions were from the students.

$\checkmark$ What changes (perception, attitudes, functioning) in girls have to be included in order to become successful managers?

$\checkmark$ What changes (perception, attitudes, functioning) in boys have to be included in order to become successful managers?

\section{Instruction:}

Below a list is given which contains certain adjectives. You are requested to rate characteristics on a five point rating scale for male/female MBA students. There is no good or bad rating since there are individual's difference in the way people think and behave. So fee free to choose which rating point you feel best describes male/female Managers. Be frank and honest. Don't hesitate to ask the researcher in any case of clarification. 
Table No. -1, Showing The Raw Score Table For Male And Female Mba Students

\begin{tabular}{|c|c|c|c|c|}
\hline \multicolumn{3}{|l|}{ Male } & \multicolumn{2}{|l|}{ Female } \\
\hline S. No. & Masculine Traits & Feminine Traits & Masculine Traits & Feminine Traits \\
\hline 1 & 190 & 187 & 252 & 228 \\
\hline 2 & 220 & 191 & 285 & 184 \\
\hline 3 & 225 & 187 & 251 & 221 \\
\hline 4 & 185 & 173 & 249 & 215 \\
\hline 5 & 235 & 219 & 210 & 187 \\
\hline 6 & 269 & 238 & 184 & 219 \\
\hline 7 & 248 & 170 & 189 & 196 \\
\hline 8 & 286 & 183 & 205 & 230 \\
\hline 9 & 247 & 202 & 198 & 190 \\
\hline 10 & 199 & 195 & 187 & 250 \\
\hline Total & 2304 & 1945 & 2210 & 2120 \\
\hline
\end{tabular}

Table No.-2, Showing The Raw Score Table For Male And Female Sucessful Managers

\begin{tabular}{|l|l|l|l|l|}
\hline Male & Female & \\
\hline S. No. & Masculine Traits & Feminine Traits & Masculine Traits & Feminine Traits \\
\hline 1 & 249 & 191 & 261 & 183 \\
\hline 2 & 223 & 221 & 246 & 187 \\
\hline 3 & 253 & 203 & 253 & 198 \\
\hline 4 & 257 & 206 & 248 & 189 \\
\hline 5 & 287 & 190 & 285 & 221 \\
\hline 6 & 197 & 193 & 242 & 225 \\
\hline 7 & 212 & 179 & 213 & 209 \\
\hline 8 & 206 & 167 & 208 & 201 \\
\hline 9 & 199 & 209 & 215 & 189 \\
\hline 10 & 200 & 207 & 236 & 192 \\
\hline Total & 2283 & 1966 & 2407 & 1994 \\
\hline
\end{tabular}

Table No. - 3, Showing The Interaction Table Of Target Person (B) Masculine And Feminine Traits (A)

\begin{tabular}{|l|l|l|l|l|l|}
\hline & $\mathbf{b}_{1}$ & $\mathbf{b}_{\mathbf{2}}$ & $\mathbf{b}_{\mathbf{3}}$ & $\mathbf{b}_{\mathbf{4}}$ & $\sum$ \\
\hline $\mathbf{a}_{\mathbf{1}}$ & 2283 & 2407 & 2304 & 2210 & 9204 \\
\hline $\mathbf{a}_{2}$ & 1966 & 1994 & 1945 & 2120 & 8025 \\
\hline$\sum$ & 4249 & 4401 & 4249 & 4330 & (1678) G \\
\hline
\end{tabular}


Table No.-4, Summary Of The Analysis Of Variance For The 2 X 4 Factorial Design

\begin{tabular}{|l|l|l|l|l|}
\hline $\begin{array}{l}\text { SOUCE OF } \\
\text { VARIATION SS(sum of square) }\end{array}$ & df & $\begin{array}{l}\text { MS (mean of } \\
\text { square) }\end{array}$ & F \\
\hline A & 356995.25 & 1 & 8569995.25 & 8.01 \\
\hline B & 2149.25 & 3 & 716.41 & 1.6 \\
\hline AB & 28618491.45 & 3 & 9539494.15 & 21.4 \\
\hline With in Treatment & 32083131 & 72 & 445599.04 & \\
\hline
\end{tabular}

[F.99 $(1,72)=7.01]$

$[$ F.99 $(3,72)=4.08]$

\section{DISCUSSION:}

Masculine and feminine the most purposive elements of personal identity which we categories our sells as either female or male. That is you may or may not pay much attention to your ethic identity or your social class or whatever but it would be extremely rare to find someone who was unaware and unconcern about being male versus being a female.

At firs the data was tabulated table no. 1 which is based on masculine and feminine traits with shows the raw score of male and female MBA students. After that we made table no. 2 which is based on masculine and feminine traits with shows the raw score of male and female successful managers. After that we made table no. 3 and 4 (instruction table and summary) table no. 3 shows the interaction of target person's and masculine and feminine traits. The interaction table has been prepared from the data in table $1 \& 2$ by entering the totals of each of the treatment combinations of the levels of factors A and B in the appropriate cells of the table. There are 8 cells entries in the interaction table. Each of the cell entries and then divide each square by 10 and subtract the correction term from the sum of square. Then we made summary table. The result of the computation in accordance with the $2 \mathrm{X} 4$ factorial design.

Dividing the sum of square by the associated $\mathrm{df}(1)$. We obtain variance estimate are mean square. The B sum square is divided by its associated df (3) next by dividing the within treatments sum of squares by its associated $\mathrm{df}$ (72) we obtain within treatment variance estimate or error mean square. Finally, F ratios are obtained by dividing the respective mean squares by the mean square. We obtain the F ratio for factor A. Factor B and AB interaction. To evaluate the $\mathrm{F}$ values we refer to the $\mathrm{F}$ table for 1 and 72 degrees of freedom. We find that the observed $\mathrm{F}$ of 8.01 for exceeds the critical value of 7.01 at 0.01 level and 3.98 at 0.05 levels. Our F value is significant both the level. Next, we consult the F table for 3 and 72 degree of freedom we again find the observed $\mathrm{F}$ of 1.60 for the main effect of $\mathrm{B}$ and 21.40 for the interaction excess the critical value of 4.08 at 1.01 level and 2.74 at 0.05 levels. So our both values are no significant difference among the male and female in perception of Masculine and Feminine because at 0.05 level the value is 3.98 and at 0.01 level the value is 7.01 which shows that our hypotheses is accepted at both level. It's means that our male and female MBA student's perception for 


\section{Masculine and Feminine Traits Perception of MBA Students}

masculine and feminine traits is similar. It's means that there is no dissimilarities in the perception of male and female MBA students.

Since there is no significant differences of masculine traits and feminine traits for target persons because at 0.05 levels the value is 2.74 and at 0.01 level the value is 4.08 . Which shows that our hypotheses are rejected its means that our target person does not perceive masculine and feminine traits similarly. There are many differences in the managers become very critical after entering into business field over masculine and feminine traits. Enviourmental pressure and competition is may be the main reason.

Since, in the last there is no significant differences at individual level and also at interactive level the significant differences at 0.05 level is 2.74 and at 0.01 level is 4.08 this further strengths the result that there is no significant interaction effect of gender and target persons on perception of masculine and feminine traits, its means whatever traits they desire for themselves as good manager they don’t perceive the same traits for the female manageress.

At the last section three, deals with the open ended questions asked by the students in the last sessions. The answer was divided into two parts. In the first part the responses given were in the terms of qualities in the form of change desirable for managers. Male students were more in favor that male manager should be mare adaptive and interactive in order to become successful managers. the male student view that girls should be more rational in taking the decision and analytical while dealing with the important issue.

The second part deals with the qualitative dissertation of male and female students for girls to become successful managers. The qualities are accepting and approving others, attractive, interactive etc. The responses given in terms of change for becoming successful managers in references to boys are that they should be co-operative, should have good manners, confident responsible etc. The traits that were common for both successful male and female are initiative decisive, logical and sincere.

\section{REFERENCES}

Amelia, M., A., Kevin, E., Grady, O., Kimberly, M., C., Kathryn, B., Vincent, H., C., Wilcox, \& Eric, D., W. (2009). Suicide ideation among college students: A multivariate analysis, Archives of Suicide Research, 13, 3:230-246.

Arun, P., \& Chavan, B., S. (2009). Stress and suicidal ideas in adolescent students in Chandigarh. Indian Journal of Medical Science, 63, 7: 281-287.

Bhalala J., N. (2014). A comparative study of suicide tendency among students in relation to gender and residential area. The International Journal of Indian Psychology, 2, 1:36-40.

Chan, W., S., Law, C., K., Wong, P., W., Law, Y., W., \& Yip, P., S. (2009). Suicidality in Chinese adolescents in Hong Kong: The role of family and cultural influences. Social Psychiatry and Psychiatric Epidemiology, 44, 4:278-284. 


\section{Masculine and Feminine Traits Perception of MBA Students}

Crosby A., E., Cheltenham M., P., \& Sacks J., J. (1999). Incidence of suicidal ideation and behavior in the United States. Suicide Life Threat Behaviour, 29:131-40.

Danie T., L., Shek, \& Lu Yu (2012). Self-harmand suicidal behaviors in Hong Kong adolescents: Prevalence and psychosocial correlates. The Scientific World Journal: 1-14.

Furr, S., R., Westefeld, J., S., McConnell, G., N., \& Jenkins, M., J. (2001). Suicide and depression among college students. Professional Psychological Research and Practice, 32: 97-100.

Ishita C. \& Jayanti B. (2010). Perceived causes of suicide, reasons for living and suicidal ideation among students. Journal of the Indian Academy of Applied Psychology, 36, 2:311-316.

Kunmi, S., Zhou N., A., J Fan, J., Liu, N., \& Sherer, R. (2014). Depression and suicidal ideation in medical students in China: a call for wellness curricula. International Journal of Medical Education, 5:31-36.

Liselotte et al., (2008). Burnout and suicidal ideation among U.S. medical students. Annals of Internal Medicine, 149, 5:334-341.

Rey, C., G., Narring, F., Ferron, C., \& Michaud, P., A. (1998). Suicide attempts among adolescents in Switzerland: Prevalence, associated factors and co morbidity. Acta Psychiatric Scandinavia, 98, 1:28-33.

Sharma, R., Grover, V., L., \& Chaturvedi, S. (2008). Suicidal behavior amongst adolescent students in south Delhi. Indian Journal of Psychiatry, 50, 1:30-33.

Vinod, K., Nagendra, K., Sanjay, D., Gouli, C., \& Kalappanavar, N., K. (2012). Prevalence and association of depression and suicidal tendency among adolescent students. International Journal of Biomedical and Advance Research, 3, 9:714-719.

Zheng, A., \& Wang Z. (2014). Social and psychological factors of the suicidal tendencies of Chinese medical students. Bio Psycho Social Medicine, 14, 23:1-4.

How to cite this article: J Bharti, S Rao (2016), Masculine and Feminine Traits Perception of MBA Students, International Journal of Indian Psychology, Volume 3, Issue 3, No. 6, DIP: 18.01.097/20160303 